„Kwartalnik Filmowy” nr 114 (2021)

ISSN: 0452-9502 (Print) ISSN: 2719-2725 (Online)

https://doi.org/10.36744/kf.824

(c) Creative Commons BY-NC-ND 4.0

\title{
Karolina Kosińska
}

Instytut Sztuki, Polska Akademia Nauk

https://orcid.org/0000-0003-1096-878X

\section{To jest trój czlowiek - idź z nim. O zakłóconej identyfikacji w filmach Alana Clarke’a}

Slowa kluczowe:

Alan Clarke;

Robert Bresson; identyfikacja; behawioryzm

w kinie;

cielesny odbiór kina; kino brytyjskie

\begin{abstract}
Abstrakt
W późnych filmach Alana Clarke’a - m.in. Made in Britain (1983), Christine (1987), Stoń (Elephant, 1989) - ujawnia się skrystalizowana, dojrzała strategia twórcza reżysera. Określają ją: skrajna redukcja i repetycyjność narracji, podkreślenie kompulsywności działań postaci, skupienie na aspektach behawioralnych przy radykalnym odrzuceniu psychologii. Strategia ta realizuje się przede wszystkim w długich, „chodzonych” ujęciach, a jej efektem jest doświadczenie cielesne, niemal transowe i specyficzna relacja widza z postaciami, a także - w konsekwencji - z samym ciałem filmu. Clarke zmusza oglądającego do nieustannego kontaktu z figurą człowieka obecną na ekranie, a jednocześnie metodycznie pozbawia go możliwości identyfikacji z nią. Autorka tematyzuje tę zakłóconą identyfikację, analizując kolejne filmy reżysera, a także lokując je w kontekście swoiście antycypujących styl Clarke'a Notatek o kinematografie Roberta Bressona oraz koncepcji teoretycznych Jennifer M. Barker dotyczących cielesnego odbioru kina.
\end{abstract}


Słoń (Elephant, 1989) Alana Clarke’a składa się z osiemnastu sekwencji przedstawiających egzekucje wykonane - najprawdopodobniej - przez jedną z północnoirlandzkich organizacji paramilitarnych. Wszystkie te sekwencje są skonstruowane niemalże identycznie: długie ujęcie (zwykle zza pleców) egzekutora idącego ku ofierze (bądź ofiary bezwiednie zmierzającej w kierunku egzekutora mającego zadać śmierć), strzał, zatrzymanie spojrzenia kamery na zwłokach. Nie mamy pewności, kto konkretnie stoi za wyrokami - w filmie nie pada ani jedno słowo. Kontekst, jakkolwiek mglisty, podsuwa nam jednak plansza rozpoczynająca film: Dla niektórych z nas "Kłopoty” sa jak słoń w naszym salonie. Owe „Kłopoty” (The Troubles) to zwyczajowe, okrzepłe już, choć przecież wciąż zaskakująco eufemistyczne sformułowanie oznaczające krwawy konflikt w Irlandii Północnej trwający od końca lat 60. XX w. Sens tej frazy został dookreślony przez Danny'ego Boyle'a, producenta filmu, następująco: Nikt o nim [słoniu] nie wspomina, bo jest tak ogromny, jest wszędzie, jest z toba cały czas, nie możesz go zignorować. A jednocześnie po 20 latach jesteś już do niego przyzwyczajony, może nawet z nim pogodzony ${ }^{1}$. Słowa te mają opisywać kształtowany przez lata stosunek mieszkańców Północy do „Kłopotów”, a jednocześnie podsuwają podpowiedzi interpretacyjne do odczytania Słonia, przedstawiając konflikt jako coś narzucającego się i determinującego wszystko, a zarazem podkreślając problematyczność jego (re)prezentacji, także medialnej.

Clarke w swoim najbardziej radykalnym filmie - pod względem zarówno formy, jak i przekazu - nie daje widzowi żadnych wskazówek, które pozwalałyby jasno określić, kto kogo zabija. Czy to republikanie strzelają do lojalistów? Czy IRA likwiduje zdrajców we własnych szeregach? Czy ofiarami są przedstawiciele brytyjskiego establishmentu w Irlandii Północnej? Tego reżyser nie ujawnia i ukazanie tego „braku” jest w zasadzie jego celem; w śmiałym geście redukuje niemalże do zera narrację i jej rozwój, psychologię bohaterów, jakąkolwiek warstwę informacyjną filmu. Zostawia widzowi kilkanaście chłodnych opisów zabójstwa podanych $\mathrm{w}$ rygorystycznym, zrytmizowanym schemacie ujęć. W schemacie tym kluczową rolę odgrywa sam marsz, wysunięty na pierwszy plan. I nie chodzi tu o metaforę drogi ku zbrodni, ale o uporczywy, miarowy krok sam w sobie, wskazujący na niepohamowany behawioralny przymus - to on stanowi o zasadniczej tkance filmu Clarke'a. Transowy (zarówno dla postaci, jak i dla widza) charakter tego marszu ujawnia się jeszcze mocniej, gdy przerywa go huk wystrzału i nagłe zatrzymanie naturalistycznego obrazu. Cykl ten odnawia się w kolejnej sekwencji i w następnej, a jego nawroty, wraz z rytmicznym pulsem kroków i wymuszonym przez kamerę dynamicznym ruchem podążania za postacią mogą doprowadzić widza do mdłości. I nie jest to reakcja na okrucieństwo egzekucji, ale na przemoc ujawniającą się w ciele samego filmu. Przemoc ta stanowi rodzaj skazy na klasycznej narracji i rozbija przyzwyczajenia odbiorcze widza. Ma jednak - z definicji moc zniewalającą.

Słoń i inne późne filmy reżysera - Made in Britain (1983), Christine (1987) i Road $(1987)^{2}$ - stawiają widzowi opór percepcyjny i powodują dyskomfort paradoksalnie właśnie dlatego, że są tak silnie behawioralne i oddziałują w tak przemożny sposób. Nie ma w nich klasycznej narracji - jest tylko ruch i zdarzenia; nie ma bohaterów - są tylko postacie; nie ma psychologii - jest jedynie dynamika. Wydaje się, że filmy te są skonstruowane tak, by wpływać nie tyle na psychikę czy emocje oglądającego, ile na jego cielesność. Klasyczna identyfikacja z postaciami 
jest tu niemożliwa, ale niemożliwa jest także ucieczka od nich; Clarke za pośrednictwem nieustannie towarzyszącej im kamery przykuwa do nich widza, nakazując tym samym jakiś odmienny, zachwiany, przymusowy typ utożsamienia. W tekście będzie mnie interesować właśnie ta swoiście zanieczyszczona identyfikacja. Podstawą teoretyzowania na jej temat jest moje własne doświadczenie odbiorcze i jego afektywna, cielesna natura. Kieruje mną przeświadczenie, że inni widzowie, podobnie jak ja, równie silnie mogą odczuwać zakłócenie identyfikacyjne, któremu poddaje nas Alan Clarke. Polegałoby ono właśnie na przesunięciu środka ciężkości z mentalnego odbioru filmu (jego narracji i fabuły) na fizyczny (albo wręcz fizjologiczny).

Wehikułem tej szczególnej strategii są u Clarke’a długie i monotonne sekwencje chodzenia - znak rozpoznawczy tychże produkcji. Czasem jest to gwałtowne parcie przed siebie (Made in Britain), czasem frenetyczna, ślepa wędrówka (Road), senna, mozolna droga (Christine) czy też zdecydowany marsz (Elephant). Sekwencje te nie łączą zdarzeń, lecz je zastępuja, tworząc zasadniczą materię wymienionych filmów. Truizmem byłoby stwierdzenie, że Alan Clarke w bardzo drobiazgowy sposób przemyślał strukturę wspomnianych dzieł - to cechuje większość dobrych reżyserów. Ponieważ jednak sam nie dawał wskazówek do ich odczytania, literatura dotycząca jego twórczości jest wciąż bardzo skromna, a przenikliwość, bezkompromisowość i śmiałość formalna filmów, o których mowa, nadal mogą budzić zdumienie (zwłaszcza że były one realizowane dla telewizji publicznej), interesuje mnie odszyfrowanie intencji reżysera oraz zbadanie mechanizmów, jakie zastosował, by osiągnąć opisany efekt odbiorczy. Chciałabym zrozumieć i wyjaśnić, na czym polega i z czego wynika potencjalny dyskomfort widza - dlaczego reżyser uniemożliwił mu tę podstawową relację z filmem, jaką jest identyfikacja z postacia, a jednocześnie nie pozwolił mu się od tej postaci oderwać. Równie interesujące będzie dla mnie przyjrzenie się, na czym polega fenomen odbioru takich behawioralnych filmów, w jakim kontekście teoretycznym można go ulokować. A także, last but not least, z czego wynika polityczny, wywrotowy charakter tej twórczości. Bowiem Clarke - kojarzony z kinem realizmu społecznego i stawiany w jednym rzędzie z innymi autorami tego nurtu: Kenem Loachem i Mikiem Leigh - podobnie jak oni jawi się w swoich filmach z lat 80. jako żarliwy i przenikliwy krytyk thatcheryzmu, stający zawsze po stronie tych, których polityka ta dotknęła najbardziej.

\section{Droga Clarke’a}

Trudno byłoby znaleźć reżysera brytyjskiego bardziej niedocenionego przez historyków kina, który jednocześnie cieszyłby się tak wielkim uznaniem wśród in-

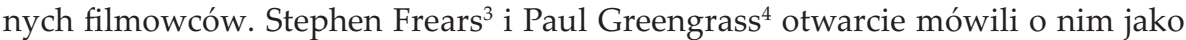
o najważniejszym twórcy telewizyjnym w Wielkiej Brytanii. Danny Boyle, współpracujący z Clarkiem jako producent Słonia, po latach powtarzał, że bez jego inspiracji nie powstałoby Trainspotting (1996). To Clarke odkrył Tima Rotha, który zadebiutował w Made in Britain, to u niego swoje pierwsze duże role zagrali Ray Winstone i Gary Oldman - wszyscy oni wielokrotnie podkreślali, jak ogromny wpływ wywarł na nich Alan Clarke. Roth przyznawał, że jednym z powodów, dla których chciał grać, była rola Winstone’a w Scum $(1977,19795)$. Kiedy lata później 


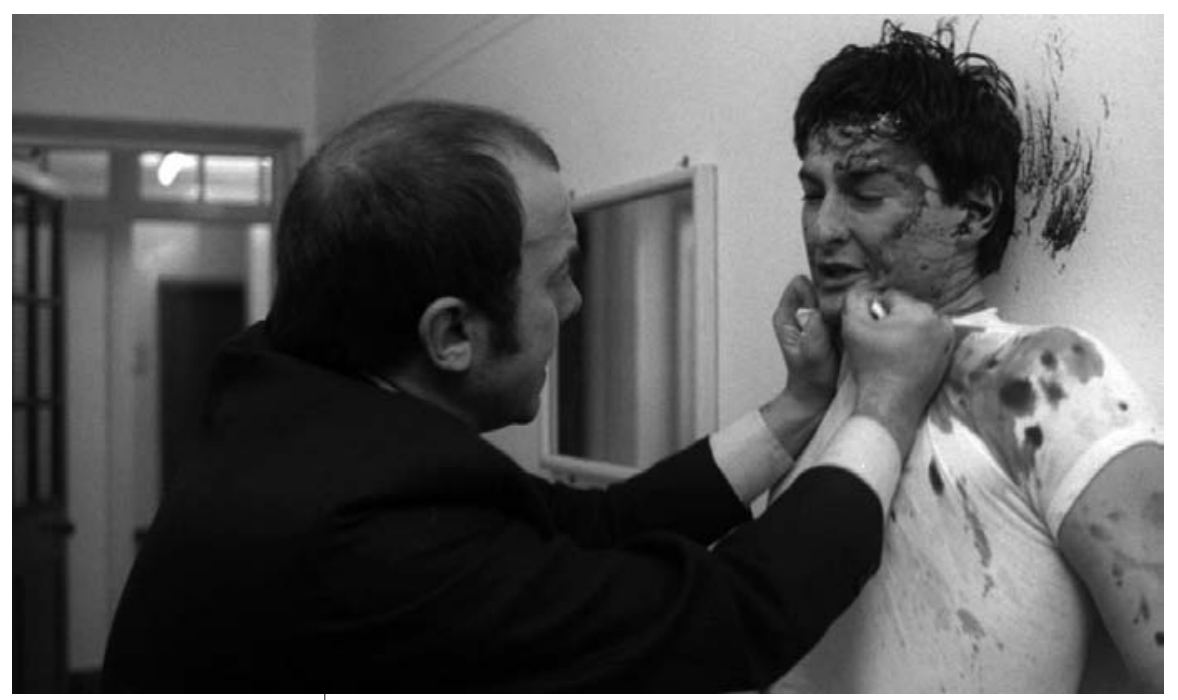

Scum, reż. Alan Clarke (1977)

reżyserował własny film (Strefa wojny /The War Zone/, 1999), w głównej roli obsadził właśnie tego aktora. Podobnie Oldman - gdy w 1997 r. zadebiutował jako reżyser autobiograficznego Nic doustnie (Nil by Mouth), oddał jedną z wiodących ról Winstone'owi. Dzięki temu oraz wyraźnemu piętnu Clarke'a, oba filmy sprawiają wrażenie złożonego mu hołdu.

W nieoczekiwany sposób ten bądź co bądź lokalny reżyser brytyjski wpłynął też na znaczących twórców amerykańskiego kina niezależnego. Harmony Korine przyznawał, że zachłysnął się filmami Brytyjczyka pokazywanymi w ramach przeglądu w MoMA', co znalazło odbicie w jego przełomowym Gummo (1997). Natomiast najsilniej i najbardziej bezpośrednio wpływ Clarke'a ujawnił się w twórczości Gusa Van Santa: Stoń (Elephant, 2003), zapożyczający od brytyjskiego poprzednika zarówno tytuł, jak i pomysł narracyjny, może być postrzegany jako próba radykalnego przełożenia sposobu my ślenia Clarke'a, twórczego wykorzystania jego strategii. Słoń z 2003 r. analizuje zbrodnię, o której opowiada, niejako metodami Stonia z $1989 \mathrm{r}$.

Przywołałam tak wielu uznanych filmowców nie po to, by ich nazwiskami uwiarygodnić czy legitymizować znaczenie Clarke’a, ale by podkreślić jego siłe oddziaływania. To on w tym układzie stanowił źródło. Co istotne, wpływ ten dotyczy przede wszystkim właśnie późnych filmów - od Scum aż do The Firm zrealizowanego na rok przed śmiercią reżysera. Cezura roku 1977 jest tu istotna, bo stanowi wyraźny przełom w jego twórczości.

Clarke rozpoczął karierę telewizyjną pod koniec lat 60 ., realizując typowe dla tego okresu television plays (głównie dla BBC i ITV) na podstawie scenariuszy młodych, poszukujących dramaturgów. Były to produkcje dość konwencjonalne formalnie, choć stopniowo coraz silniej ujawniała się w nich jego prowokacyjna natura i skłonność do poruszania kontrowersyjnych tematów społecznych, czasem też politycznych. Od początku interesował go problem przemocy - zarówno tej w relacjach międzyludzkich, jak i leżącej u podstaw wszelkiej władzy. Przemoc tę ujmował jako coś organicznego, behawioralnego, a przy tym zawsze nacechowa- 
nego społecznie i skrajnie sfunkcjonalizowanego $\mathrm{w}$ ramach różnych instytucji. Ostatecznie w 1977 r. tolerancja BBC dla bezkompromisowości Clarke'a się wyczerpała - stacja zatrzymała kontrowersyjny Scum opowiadający o zinstytucjonalizowanej przemocy w zakładach poprawczych, a także o sankcjonowaniu przez ich władze hierarchicznej agresji między wychowankami. BBC nie mogła sobie pozwolić na tak otwartą krytykę innej publicznej instytucji - film trafił na półki. Efektem takiego symbolicznego wyrzucenia poza ramy systemu było uwolnienie niezwykłej energii twórczej Clarke’a - jak gdyby od tej pory nie krępowały go już żadne ograniczenia i konwencje. Od momentu zatrzymania Scum reżyser zaczął radykalnie eksperymentować z narracją a jego dojrzały styl gwałtownie się skrystalizował: kolejne filmy miały coraz silniej zredukowaną strukturę fabularną i psychologię postaci, długie sekwencje chodzenia coraz mocniej wypierały zdarzenia, coraz wyraźniej była też widoczna strategia in-your-face: forsowania własnego, czasem brutalnego spojrzenia, bez dbałości o komfort widza i stosowania się do przyjętych konwencji.

\section{Made in Britain, Road - negatywna energia}

Świadectwem uwolnienia tej nowej energii była kinowa wersja Scum z roku 1979. Jednak dopiero w Made in Britain, zrealizowanym na podstawie scenariusza Davida Lelanda, Clarke zasygnalizował zerwanie z konwencjonalnym prowadzeniem narracji; następne filmy w coraz bardziej widoczny sposób rozsadzały tradycyjną formułę kina fabularnego, stając się radykalną próbą przeanalizowania konkretnych problemów społecznych czy politycznych już nie na poziomie treści, ale samej formy filmowej ${ }^{7}$. Made in Britain to początek tej drogi. Głównym bohaterem jest Trevor (Tim Roth), nastoletni skinhead, który nie chce się poddać systemowi resocjalizacyjnemu. Clarke rysuje tu wyrazisty portret thatcheryzmu, którego sam Trevor jest wytworem, będąc jednocześnie jego wyrzutkiem. Chłopak zostaje zatrzymany, osądzony, skierowany do ośrodka poprawczego, z którego ostatecznie ucieka. Struktura fabularna ma tu jednak znaczenie jedynie ustanawiające: sednem filmu jest nieustanna dyskusja między Trevorem a systemem, prowokacyjna współzależność, a przede wszystkim jej dynamika, ruch (kontrastujący z zamknięciem), utożsamiony z uporczywym, niepohamowanym marszem Trevora. Sekwencje tego marszu nie muszą być uzasadniane fabularnie - większość sprawia wrażenie "gratisowych", wynikających nie z potrzeby zachowania porządku przyczynowo-skutkowego, ale z wewnętrznego przymusu postaci. To nie punkt dojścia jest istotny, ale samo agresywne parcie do przodu. Zasadniczym narzędziem pozwalającym reżyserowi na wyakcentowanie tej dynamiki jest Steadicam, którego zastosowanie stanie się odtąd jego znakiem firmowym. Steadicam (tu prowadzony przez Chrisa Mengesa) pozwalał reżyserowi na obserwację postaci w ruchu w długich, płynnych, niezakłóconych montażem i drganiem ujęciach. W ten sposób twórca ustanawiał specyficzna, opartą na dyskomforcie relację między postacią a widzem. Trudno identyfikować się z Trevorem - przede wszystkim z racji jego oporu, a także ze względu na niechęć do utożsamiania się z tego rodzaju antybohaterem. Jednak Clarke nie poucza i nie przyjmuje protekcjonalnego tonu: Trevor jest neonazista, ale potrafi myśleć; jego poglądy mogą być nie do przyjęcia, ale trzeba je wypowiedzieć na głos. Nakazując kamerze nieustannie towarzyszyć bohaterowi, reżyser niejako 


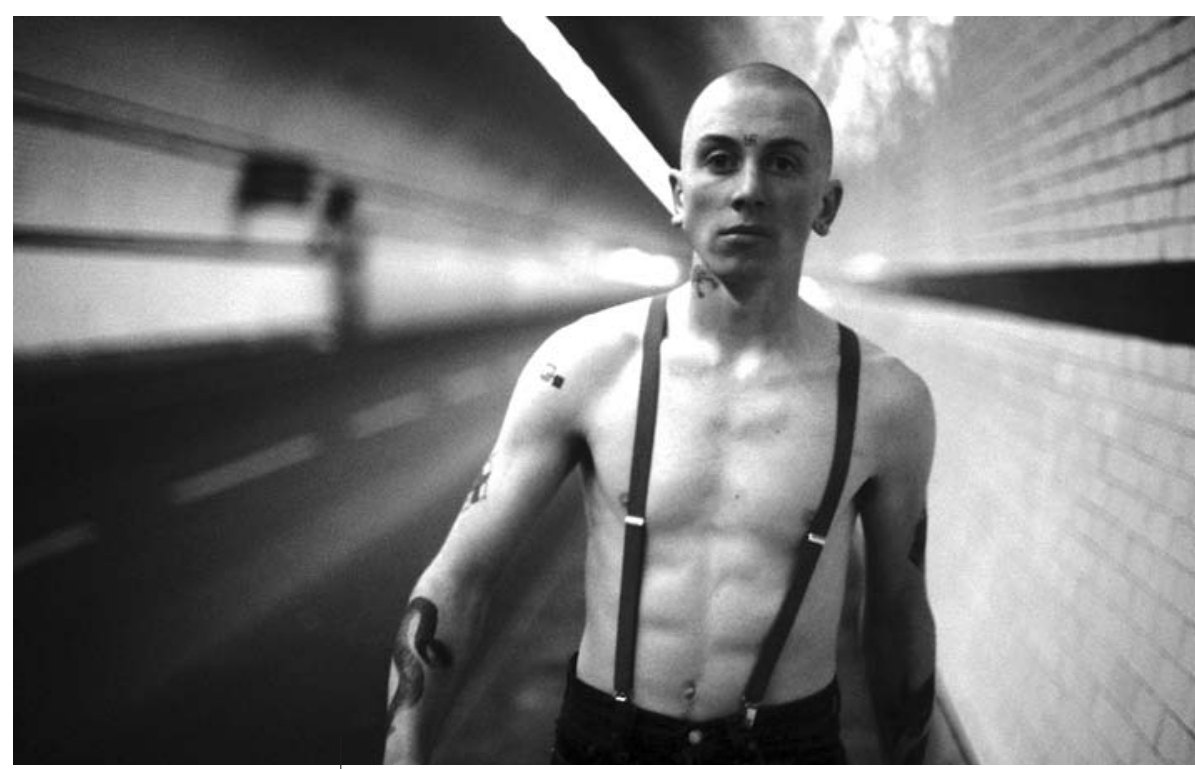

Made in Britain, reż. Alan Clarke (1983)

przykuwa widzów do niego, nie pozwala im odwrócić oczu. Tim Roth doskonale ujął intencję reżysera: Pierwsze ujęcie to bardzo duże zbliżenie Steadicamu na mnie, gdy wchodzę do sali sądowej. To typowe zagranie Alana. Jakby mówit: To jest twój człowiek, idź $z$ nim $^{8}$. W Made in Britain nie ma nikogo innego, z kim widz mógłby się związać. Pozostając przy Trevorze, musi go wysłuchać, przetrawić jego racje. To jednak nie wszystko - oglądający jest skazany na współodczuwanie z nim, nie w sensie mentalnym, ale czysto fizjologicznym. Oglądając długie ujęcia marszu chłopaka, odbiorca zgrywa się z rytmem jego kroków, przenosi na własne ciało jego (negatywną) energię. Ten typ percepcji wydaje się tu dominujący.

Podobna gwałtowność stanowi esencję późniejszego o cztery lata Road, adaptacji sztuki teatralnej Jima Cartwrighta. Road nie opowiada spójnej historii, ale raczej tematyzuje upadek północnoangielskich miast przemysłowych i wspólnoty robotniczej w dobie deindustrializacji właściwej thatcheryzmowi. Kontekst ten ma zasadnicze znaczenie, bowiem miejsce, w którym realizowano film - upadłe, na wpół opuszczone górnicze osiedle przy kopalni Easington - pełni funkcję jednego z bohaterów. Clarke umiejscawia w tej przestrzeni (niejako wbrew tekstowi dramatycznemu wychodząc w plener) czworo swoich bohaterów. Jednakże Carol, Louise, Brink i Eddie - choć znamy ich imiona - nie są tak zindywidualizowani jak Trevor. Oni także wyrażają siebie przez nieustanny ruch i niepohamowane, jak gdyby wyrzucane z trzewi monologi (czasem dialogi), ale konstrukcja tych postaci każe myśleć, że są jedynie figurami świata, który reprezentują a nie jednostkami o własnej, pogłębionej psychologii. Ich ekspresją rządzi nadmiar i kompulsywność skontrastowana z martwotą miejsca - bohaterowie idą i mówią ich ruchliwość sprawia wrażenie natręctwa, nerwowego rozładowywania skumulowanej energii. Dave Rolinson widzi w takiej strategii estetycznej ścisły związek z krytyką thatcheryzmu - według niego Clarke, przestawiajac postaci wędrujace donikad przez opuszczone osiedla, pokazuje, jak w sytuacji bezrobocia marnuje się witalność proletariatu' ${ }^{9}$. 
Podobnie postrzega to John Hill, stwierdzając, że ujęcia te są nośnikami wymiaru semantycznego, dając wyraz energii i wewnętrznej prężności postaci, mimo opresyjności ich otoczenia $i$ desperacji, jaka odczuwają ${ }^{10}$. Ta energia, zderzona z inercją i rozpadem samego miejsca, okazuje się bezcelowa, bo nikomu niepotrzebna. Dlatego też jej dynamikę z taką siłą narzuca widzowi reżyser. Frenetyczny rytm kroków i stukot obcasów dopełnia "pulsowanie” samego obrazu: zastosowanie Steadicamu znów włącza widza w ruch postaci, ale dodatkowym wzmocnieniem jest tu uwypuklona sekwencyjność architektury stanowiącej dla nich tło. Ulice, którymi wędrują bohaterowie, są jednakowe, przy każdej stoi rząd takich samych domów. Miarowość marszu zgrywa się z wizualnym rytmem mijanych budynków, dając jeszcze silniejszy efekt transowy. Jego kulminacją jest wyizolowana ze szczątkowej fabuły Road kilkuminutowa scena wędrówki Valerie, anonimowej mieszkanki zdewastowanego osiedla, stanowiącej niejako jego emblemat. Towarzyszący jej drodze monolog to rozpaczliwa próba wyrażenia frustracji kobiety zamkniętej w pułapce rzeczywistości, w której proletariat (i jego etos) został sprowadzony do lumpenproletariatu, z właściwymi mu nędzą, brzydota, degradacją wartości i przemocą patriarchalną. Ten monolog, brzmienie słów i poszczególnych głosek, także ma swój rytm. Ostatecznie wszystkie te elementy - powtarzalność architektoniczna, ruch ciała, stukot kroków i puls wypowiadanego tekstu - składają się na wibrująca, transową rytmiczność. Psychologiczne i mentalne odczytanie następuje dopiero po reakcji zmysłowej. Zrozumienie tego, o czym mówi kobieta, przychodzi przez dyskomfort ciała odbiorcy. Strategia ta zdaje się istotą także innych scen w Road, w których zasadnicze znaczenia niosą nie wydarzenia fabularne, ale raczej wizualna (scenograficzna) szpetota, dysonanse, groteskowe zestawienia, nadmiarowa kompulsywność działań i monologów postaci. Natomiast działanie ruchomej kamery znaczaco wychyla się poza konwencjonalny zwiazek $z$ realizmem i dokumentalizmem, generując kinetyczne i rytmiczne wzory (...) przekraczające wymagania zarówno logiki narracyjnej, jak i ekspresji symbolicznej ${ }^{11}$. To właśnie owe wzory - nie logika czy symbolika - stanowią sedno tak strategii autorskiej, jak i sytuacji odbiorczej.

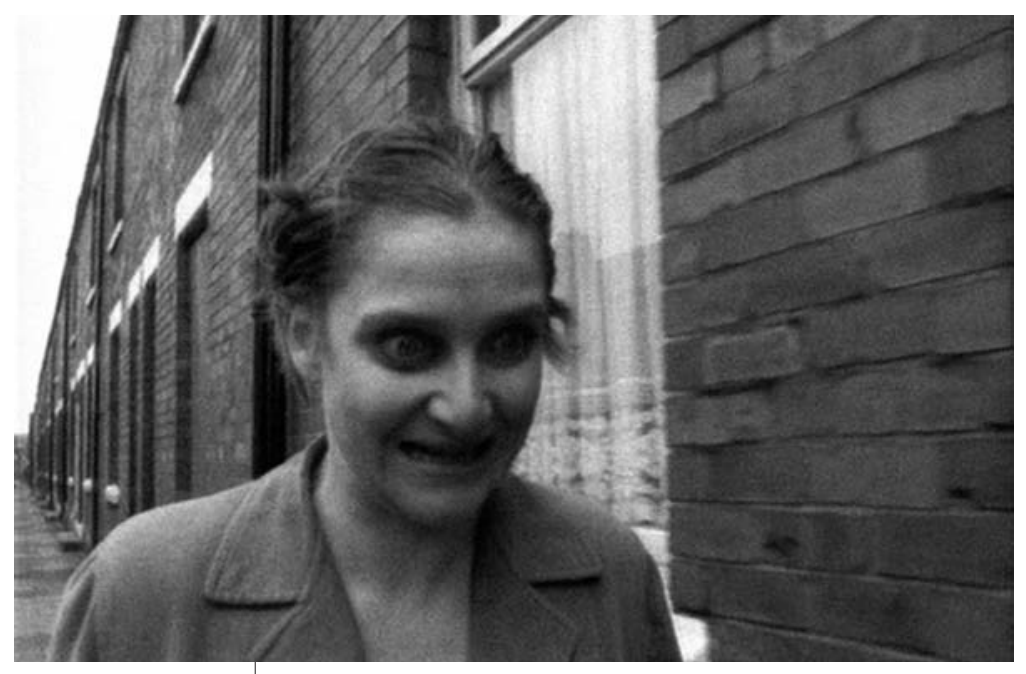

Road, reż. Alan Clarke (1987) 


\section{Christine, Stoń - redukcja i przymus powtarzania}

W Made in Britain i Road można dostrzec podobną energię oraz dynamikę. W obu tych filmach Clarke dużą wagę przykłada także do języka: nerwowe słowotoki pozwalają postaciom skanalizować frustracje, ale mają też inną funkcję oddania głosu tym, którzy zwykle go nie mają. W finałowej scenie Road Louise formułuje niezwykle istotną konstatację: Jeśli będę krzyczeć, to może jakoś, jakoś uda mi się uciec. Powtarza to zdanie, po czym podchwytuje je reszta postaci, skandując je z taką mocą i tyle razy, że nabiera ono mocy manifestu.

Zupełnie inaczej rzecz ma się z Christine i Słoniem, z których słowo zostało niemalże wyrugowane. Filmy te są bliźniacze pod jeszcze innym względem: skrajnemu ogołoceniu fabularnemu (i werbalnemu) towarzyszy przyjęcie repetycji jako zasady konstrukcyjnej. W obu powtarzane segmenty mają też taką samą strukturę: przedłużona obserwacja idącej postaci (przy użyciu Steadicamu), zdarzenie i zatrzymanie narracji. Co więcej, zarówno w Christine, jak i w Słoniu owe zdarzenia można określić tym samym słowem - shot (strzał). W drugim z filmów chodzi o uśmiercający ofiarę wystrzał z broni. Natomiast w pierwszym takim strzałem jest zastrzyk heroinowy.

W Christine nie ma już punktu wyjścia i punktu dojścia. Kamera podąża za kilkunastoletnią dziewczyna, która wędruje od domu do domu, by sprzedać innym nastolatkom działkę heroiny. Idzie bez słowa, jej twarz jest pozbawiona wyrazu, z „klientami” prowadzi całkowicie beznamiętne rozmowy o niczym, pomaga przygotować strzykawkę i wbić igłę w żyłę. Czasem sama też się szprycuje, po czym, gdy tylko narkotyk zacznie działać, następuje spowolnienie. Kamera, która nie odstępuje Christine na krok, zatrzymuje się, bezruch postaci przekłada się na statyczność obrazu. Kolejne sekwencje wyglądają dokładnie tak samo.

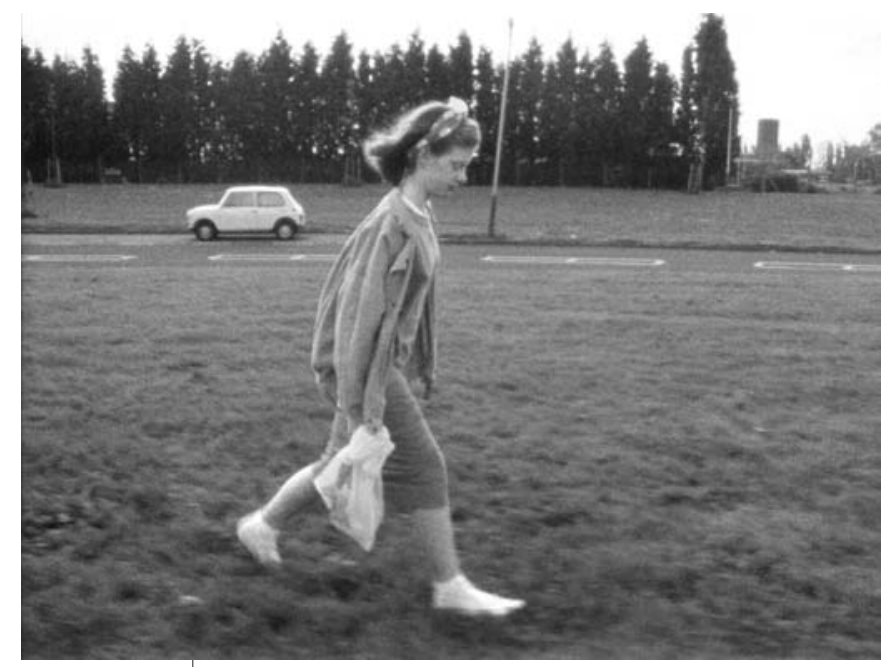

Christine, reż. Alan Clarke (1987) 
Moc działania Christine wynika z niemocy zaakcentowanej w konstrukcji filmu. Jego scenarzysta, Arthur Ellis, przyjął bardzo klarowną koncepcję: $w$ narkotykach nie ma żadnej dramaturgii: bierzesz i umierasz. To nie najlepszy napęd dla narracji. Tak więc albo idziesz w totalna nude, albo w ohydę $e^{12}$. Wybór był oczywisty ${ }^{13}$ : Chciałem usunać wszelka anegdote, niech to będzie cholernie nudne. (...) Jedenastolatka ${ }^{14}$ chodzi od miejsca do miejsca, wchodzi do domu, wbija igłe w ramię. Tyle-chodzenie i szprycowanie. Oczywiście, w "Road" także było chodzenie, to byt cholerny maraton, ale tam były postacie, ruchome portrety ludzkich istot i wspaniały tekst Jima Cartwrighta. W "Christine" sa tylko dzieciaki i ich "wszystko w porzadku?". Wyrzuciliśmy każda rzecz, która dawałaby jakikolwiek posmak dramaturgii ${ }^{15}$. Suspens wyczerpywał się już w pierwszej sekwencji, każda kolejna była poddana przymusowi powtarzania. Co więcej, Clarke nie zaoferował żadnej konkluzji czy oceny moralnej. Po prostu pozostawił widza sam na sam z Christine, dając mu jej obraz, ale uniemożliwiając identyfikację - to postać bez jakiegokolwiek rysu psychologicznego, figura wyłącznie cielesna. Spłaszczenie narracyjne jest tu dojmujące, temperatura emocjonalna scen spokojnego marszu dilerki i wstrzykiwania heroiny jest dokładnie taka sama. Nie ma różnicowania dynamiki. Efektem odbiorczym takiej monotonnej repetycyjności i ustawienia relacji postać - widz jest jednoczesne zanurzenie (jak w transie) i odrzucenie. Uporczywa powtarzalność cyklu ma jeszcze jedną konsekwencję: scena wbijania igły w żyłę może za pierwszym razem powodować jakiś wstrząs czy chociażby pobudzenie widza, ale wielokrotnie powtórzona traci tę moc. Widz się znieczula, martwieje, doświadczenie filmu może się zamienić w hipnotyczną udrękę. Znamienna wydaje się tu reakcja Stephena Frearsa: "Christine” - ćpuny na osiedlu. Nie mogłem tego ogladać. Kamera z ręki sprawiła, że wszystko było jeszcze bardziej przygnębiajace bo pozwalała filmować wędrówkę z jednego domu do drugiego. Nie dało się od tego uciec. To oczywiście świetny pomyst. Ale przez to nie byłem w stanie ogladać filmu - czy to dobrze, czy źle? ${ }^{16}$

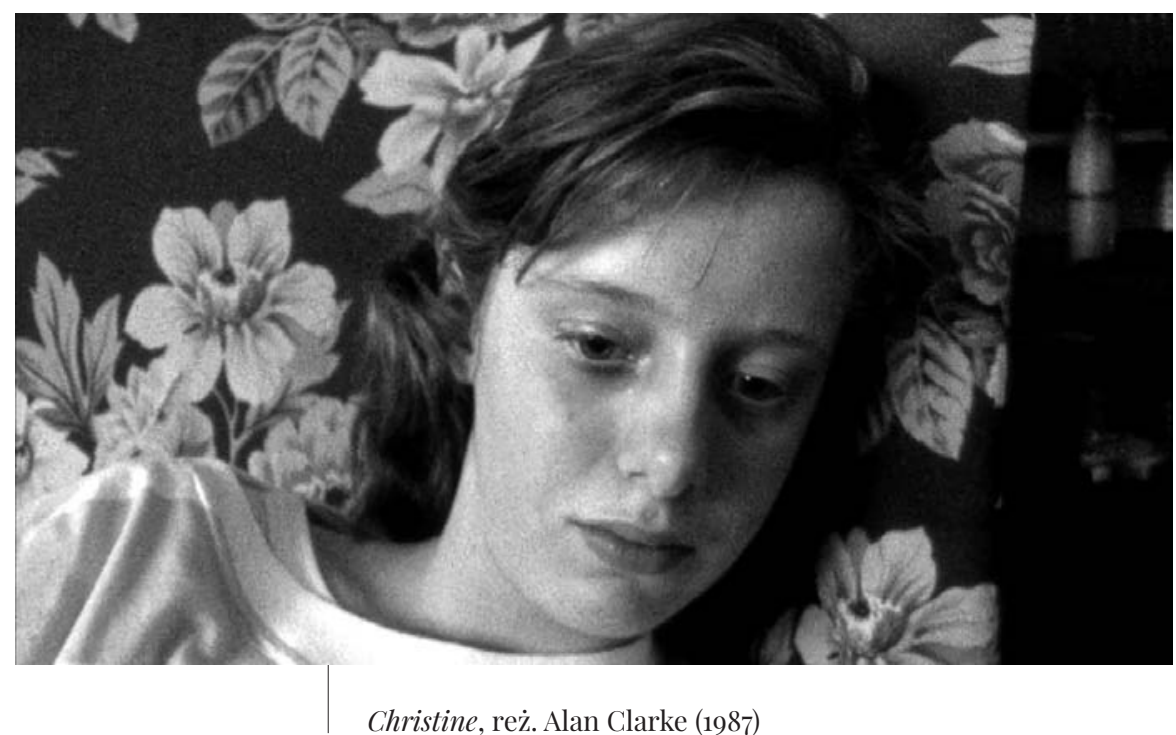


Kulminacją i krystalicznym przykładem dojrzałej, bezkompromisowej strategii reżysera jest jednak bezsprzecznie Słoń, sprawiający wrażenie eksperymentu (jak najbardziej udanego) badającego granice komunikatywności narracji. Swoistym wstępem do niego jest równie konceptualny, a jednak bardziej przystępny w odbiorze Contact Clarke'a z 1984 r., także problematyzujący konflikt w Irlandii Północnej. Contact ukazuje sytuację żołnierzy brytyjskich stacjonujących przy granicy z Republiką Irlandii. Główny bohater filmu, dowódca plutonu, każdego dnia prowadzi swój oddział na rutynowe patrole mające na celu wyłapanie bojowników IRA działających na terenach przygranicznych. Powtarzalność i monotonia koszarowego życia oraz codziennych obchodów mają przeciwwagę w brutalnych konfrontacjach z (domniemanymi) terrorystami. Skrajne napięcie towarzyszące tym naprzemiennym sytuacjom odbija się na psychice dowódcy. Clarke niuansuje dynamikę poszczególnych sekwencji i precyzyjnie buduje wiarygodną postać dowodzącego - to znacząco ułatwia odbiór filmu, a jego przekaz, o charakterze wyraźnie politycznym, daje się dość łatwo odczytać.

Stoń wybija widza z takiej stosunkowo komfortowej (bo konwencjonalnej) pozycji. Reżyser bierze na warsztat niezwykle skomplikowany, wielopłaszczyznowy konflikt zbrojny, po czym zamyka go w precyzyjnej, choć nierozbudowanej strukturze. Cała złożoność „Kłopotów” zostaje sprowadzona do kilkunastokrotnego powtórzenia sekwencji: droga - zdarzenie - zatrzymanie (a jeszcze prościej: ruch - wstrząs - bezruch). Nie znamy ani tożsamości, ani nawet przynależności organizacyjnej zabójców i ofiar. Postacie to znowu jedynie cielesne figury odprowadzane przez kamerę (a więc i widza) na miejsce egzekucji. Droga prowadzi przez opustoszałe ulice, zimne postindustrialne przestrzenie, bezimienne tereny. Tylko ci, którzy dobrze znają Belfast, rozpoznają w filmie to miasto.

Tak radykalna redukcja może stanowić o trudności w odbiorze, ale jednocześnie otwiera film na wielość odczytań. Pierwsze, najbardziej się narzucające, jak pisze Michael Walsh, wskazywałoby, że film ów to bezlitosna demonstracja tego, do czego rzeczywiście sprowadza się konflikt w tych sześciu hrabstwach, sugerujaca, że niezależnie od całej historii Irlandii, jej polityki $i$ ideologii, naga rzeczywistość jest taka: anonimowi ludzie podjeżḋaja lub podchodza pod drzwi innych ludzi i zabijaja ich ${ }^{17}$. Wszelkie usprawiedliwienia i uzasadnienia nie są tu istotne. Drugie odczytanie odsyła do kwestii niepojętości - podkreślona w filmie niezrozumiałość, jak najbardziej konkretna (brak wyjaśnienia, kto i dlaczego robi to, co robi, jaki kontekst tłumaczy te działania), przekłada się na symboliczną niepojętość samego konfliktu ${ }^{18}$. Ważny trop proponuje też Dave Rolinson, wskazując, że Słonia można odczytywać jako złamanie konwencji, zwyczajowych kodów przedstawiania „Kłopotów” w mediach. Film Clarke'a miałby być wymierzony w uładzony, a przy tym zideologizowany (bo wyjaśniający sprawę kategoriami wygodnymi dla władzy) sposób prezentowania konfliktu, proponując obraz nieprzystający do przyzwyczajeń odbiorców i rozbijający je ${ }^{19}$. Wszystkie te sugerowane odczytania odwołują się do mentalnego przepracowania tego, o czym mówi Słoń, pomijając sam sposób oddziaływania na widza. Sprowadzając przedstawione wydarzenia (a więc i sam konflikt) do sytuacji czysto behawioralnych, reżyser niejako narzuca równie behawioralny odbiór. To najbardziej transowy film Alana Clarke'a, ponieważ określone „wzory kinetyczne” nie są tu niczym zakłócone. Każdy akt zbrodni jest przedstawiony wprost, z dużą dozą naturalizmu; widz musi się z nim mierzyć kil- 


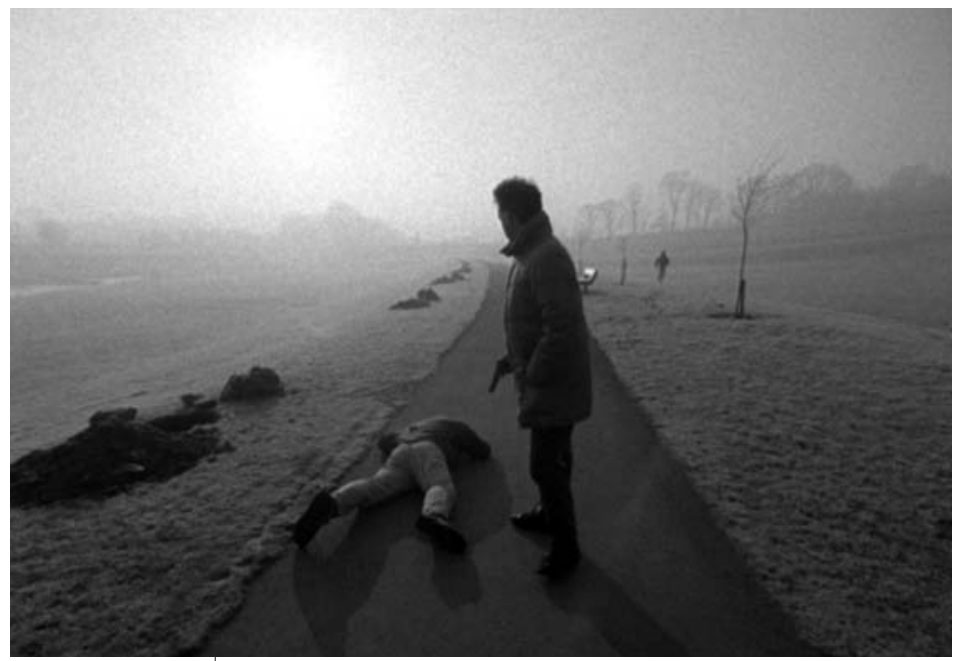

Słoń, reż. Alan Clarke (1989)

kanaście razy; przez cały czas jest prowadzony, za sprawą pracy kamery, po czym przytrzymywany, niemalże siła, by przez dłuższą chwilę konfrontować się z konsekwencjami przemocy. David Leland, pisarz, reżyser i aktor często współpracujący z Clarkiem, wspomina swój pierwszy kontakt ze Słoniem, kiedy film był emitowany w telewizji: Pamiętam, jak ogladałem go, leżąc w łóżku, i myślałem: "Przestań, Alan, nie możesz tego tak ciagnaćc. Ostateczny efekt jest taki, że mówisz sobie: „To się musi skończyć. Zabijanie musi się skończyć". Instynktownie, poza procesem myślowym, to reakcja trzewi ${ }^{20}$. Tak więc (z)rozumienie przychodzi przez ciało i zmysły. Clarke'owi udało się znaleźć taką formę i narzędzia, które pozwalają obezwładnić widza, zmuszając go do silnej reakcji fizycznej. Hipnotyczny dyskomfort - to chyba najbardziej adekwatne określenie tego stanu.

\section{Między więzią a obcością}

Droga Alana Clarke'a od Made in Britain do Słonia wydaje się bardzo konsekwentna - jakby redukując formę, próbował znaleźć absolutną esencję o jak największym potencjale znaczeniowym. Dzięki temu „prawie nic”, do którego ostatecznie doszedł, wskazywało na „niemal wszystko”. Omówienie kolejnych filmów pozwala na podsumowanie precyzyjnej, stale cyzelowanej strategii formalnej reżysera, którą określają: skrajny minimalizm i repetycyjność narracji, wyakcentowanie kompulsywności działań postaci, skupienie na behawioryzmie przy radykalnym odrzuceniu psychologii. Strategia ta realizuje się głównie w długich "chodzonych" ujęciach, a jej efektem jest przede wszystkim doświadczenie transu i specyficzna relacja widza z postaciami, zaś w konsekwencji z samym ciałem filmu. Clarke zmusza oglądającego do nieustannego kontaktu z figurą człowieka obecną na ekranie, a jednocześnie metodycznie pozbawia go możliwości identyfikacji z nią. Kontakt jest stały, ale zawsze niepełny, zaburzony.

Kluczowe znaczenie dla budowania tej relacji ma prowadzenie kamery oraz wykorzystanie Steadicamu. Mechanizm ten umożliwia pokazanie płynnego ruchu, niezakłóconego montażem, ale - jak wskazuje Dave Rolinson - problematyzuje 
także różnicę między subiektywizmem a obiektywizmem spojrzenia kamery, między uczestnictwem a obserwacją ${ }^{21}$. Zdaniem badacza Clarke odchodzi od widocznej pasywności techniki obserwacyjnej w kierunku retoryki uczestniczącej, będącej efektem zastosowania Steadicamu ${ }^{22}$. Rolinson przekłada to rozróżnienie na przeciwstawienie naturalizmu (typowego dla kina np. Kena Loacha) realizmowi krytycznemu (jego przedstawicielem wedle teoretyka jest właśnie Clarke): podczas gdy strategia naturalizmu zakłada prezentowanie wydarzeń z pozycji obserwatora, realizm krytyczny ukazuje rzeczywistość filmową z punktu widzenia uczestnika ${ }^{23}$. Wydaje się jednak, że w przypadku filmów Clarke'a chodzi nie o uczestnictwo wraz z postaciami w świecie przedstawionym (jakbyśmy stali obok nich), lecz właśnie o obserwację, tyle że jej przedmiotem jest sama postać, a w zasadzie figura postaci, model. To związek z nia, nie z rzeczywistością filmowa, jest tu istotny. Rolinson, analizując Made in Britain, przywołuje niezwykle trafną konstatację Howarda Schumana, według którego film ten niepokoi nie z powodu przemocy, która jest przede wszystkim werbalna i mentalna, ale raczej z racji wahnięć między więzia [attachment] a oderwaniem [detachment], bliskościa a dystansem, energia kinetyczna a statyczna dys$k u s j q^{24}$. Rolinson dopowiada, że owo rozbicie jest spowodowane także tym, że zwiqzek kamery z Trevorem jest jednocześnie usidlajacy i uwalniajacy ${ }^{25}$. Spostrzeżenie to odnosi się bezpośrednio do sposobu operowania ruchem i statycznością w Made in Britain: gdy bohater jest w ruchu, kiedy kamera podąża za Trevorem, widz ma do czynienia z narracją subiektywna, prowadzoną niejako z pozycji bohatera; natomiast w scenach zatrzymania, gdy Trevor jest przesłuchiwany albo gdy zostaje zamknięty w ośrodku, obraz staje się obiektywny, wskazując na prymat narracji oficjalnej, reprezentującej władzę. Zakłócenie czy też zatrzymanie mobilności chłopaka natychmiast konotuje opresyjność władzy i właściwej jej ideologii ${ }^{26}$.

Rozpoznanie, że niepokojący, rozstrajający widza charakter Made in Britain wynika z nieustannego oscylowania między bliskością i więzią a jej zerwaniem i dystansem, daje się przełożyć także na pozostałe omawiane tu filmy. W efekcie - zwłaszcza jeśli uwzględnimy behawioryzm i skrajne „odpsychologizowanie” postacie przestają być bohaterami, bo identyfikacja z nimi jest niemożliwa. Nie są też jedynie postaciami (figurami), bo pozwalają intuicyjnie wyczuć, jaki ciężar ze sobą niosą. Być może najwłaściwiej byłoby nazwać te byty nie-bohaterami: un-hero czy un-heroine, aby użyć określenia z tekstu Andrew Clifforda ${ }^{27}$. Najtrafniej oddaje ono też samą strategię twórczą Clarke’a.

\section{Clarke a Bresson}

Czas zastanowić się, jak szerzej umiejscowić tę Clarke'owską strategię i gdzie szukać wyjaśnienia tak intensywnie cielesnego oddziaływania jego filmów. Wynik tych poszukiwań może być zaskakujący. Okazuje się bowiem, że twórczość Clarke'a - w sposobie rozumienia i konstruowania narracji świata przedstawionego oraz postaci - jest zadziwiająco bliska temu, co o metodach kreowania dzieła filmowego pisał Robert Bresson. Podkreślam, że chodzi o prace teoretyczne, nie o samą twórczość francuskiego reżysera, która funkcjonuje w całkowicie innym uniwersum. W Notatkach o kinematografie (Notes sur le cinématographe, 1975) bardzo wyraźnie określa on swoje credo, zamykając je w krótkich frazach mających charakter konstatacji, wskazówek, czasem wręcz przykazań dla innych twórców. Trudno byłoby 
znaleźć w źródłach czy w wypowiedziach samego Clarke'a odniesienia do Bressona. W zbiorze zredagowanym przez Richarda Kelly'ego, gromadzącym wspomnienia filmowców współpracujących z Clarkiem, tylko raz pada nazwisko francuskiego reżysera. Dramaturg Roy Minton, autor scenariusza Scum, dostrzegł podobieństwa obu twórców, choć widział je na poziomie samych realizacji filmowych. Według niego Clarke wypracowat bardzo rygorystyczny język, można powiedzieć - styl. Tylko że polegało to na niemal całkowitym porzuceniu stylu. Myśle, że stał sie figura swoiście bressonowska. Alana interesowała istota chwili, jak sprawić, by dała się ustyszeć i zobaczyć. I tu Bresson staje się ważnym odniesieniem. Bresson potrafit pokazać bardzo prosta rzecz w taki sposób, że wydawata się nieprawdopodobnie petna znaczeń (...). Oczywiście Alan skomentowałby porównanie z Bressonem zwykłym "Bzdury!". Nie sadzę, by fantazjowat o sobie jako reżyserze, z pewnościa też nie podchodzit do pracy z typowa dla Bressona świadomością. Ale szukał tego samego i ostatecznie zabierał nas właśnie w stronę surowości, widocznej prostoty ${ }^{28}$. Warto podkreślić różnice między obydwoma reżyserami: w filmach Clarke'a rygoryzm i minimalizm ujawniają głębię znaczeń, ale nigdy nie ma ona charakteru metafizycznego. Wydaje się raczej, że intuicyjnie, szukając istoty (filmowości?), dochodzili do podobnych wniosków, znajdowali podobne narzędzia, choć cele i intencje mieli całkowicie odmienne.

Niemniej Notatki o kinematografie w rozlicznych fragmentach wydają się doskonałym wprowadzeniem do metody Clarke’a czy też narzędziem do jej interpretacji, choć oczywiście trzeba tu odrzucić przekonanie, wyczuwalne w uwagach Bressona, że ostatecznie stawką filmu jest coś metafizycznego, wewnętrzna wolność, tajemnica. Twórczość Brytyjczyka ma własną głębię, może nawet wyraża swoistą filozofię (kompulsywny behawioryzm postaci jako metafora funkcjonowania człowieka w świecie), ale ostatecznie nigdy nie wykracza ona poza złożoną diagnozę społeczną czy polityczną. Tu nigdy nie chodzi o duchowość - zawsze o pragmatyczne, ludzkie "tu i teraz”. A jednak środki, za pomocą których obaj twórcy dochodzili do własnych celów, mogą się wydać bliźniacze. Warto przywołać tu rozważania Susan Sontag o duchowym stylu francuskiego reżysera. Zestawiając jego metodę z koncepcjami Bertolda Brechta ${ }^{29}$, Sontag pisze: Bresson także stara się stworzyć dystans, lecz sądze, że jego intencja nie jest schtadzanie goracych emocji, tak by mógł nad nimi przeważyć intelekt. Wydaje się, że charakterystyczny dla jego filmów dystans emocjonalny jest w nich obecny z zupetnie innego powodu. Bresson wprowadza go, ponieważ utożsamianie się z postaciami i ich głębokie rozumienie to bezczelność, afront wobec tajemnicy, jaka sa ludzkie czyny i ludzkie serca. Jeśli jednak odsunać kwestię intelektualnego chłodu i szacunku dla tajemnicy czynu, Brecht był świadom, a i Bresson musi zdawać sobie z tego sprawę, że dystans jest wspaniałym źródłem sity emocjonalnej. Defekt naturalistycznego kina i teatru tkwi właśnie w tym, że zbyt łatwo oddaja się one widzowi, przez co szybko konsumuja i wyczerpuja własne efekty. Najlepszym źródłem sity emocjonalnej w sztuce nie jest żaden określony temat, nawet najbardziej namiętny i uniwersalny, lecz forma. Świadomość formy oddala i schładza emocje, co w ostatecznym rozrachunku wzmacnia je i intensyfikuje ${ }^{30}$. Zapewne w przypadku Clarke'a metodyczne uniemożliwianie identyfikacji widza z postacią nie wynika z przekonania, że byłaby to impertynencja wobec tajemnicy, ale - jeśli właściwie interpretuję jego filmy z przeświadczenia, że ciało, jego dynamika i rytm, wpisanie w przestrzeń, cała powierzchnia obrazu filmowego mogą mówić wyraźniej i głośniej niż czytelna psychologia bohatera. Nie chodzi tutaj także o oddanie pola inteligencji interpretatora, 
ale o torowanie drogi do zrozumienia przez doświadczenie zmysłowe, jakkolwiek nieprzyjemne i niewygodne.

Wystarczy jednak sięgnąć bezpośrednio do notatek Bressona, zwłaszcza tych, które dotyczą aktorstwa i ekonomii narracji. Zatem przede wszystkim nie aktor, ale model. Różnica jest zasadnicza i odnosi się do sposobu jego funkcjonowania w filmie i na ekranie: chodzi o to, by Być (modele) zamiast pozorować (aktorzy) ${ }^{31}$. Model ten to w największym skrócie: Para ruchomych oczu, w ruchomej głowie, osadzonej na ruchomym tułowiu ${ }^{32}$. Bresson formułuje swoje uwagi co do sposobu i zasadności wykorzystania tej figury jako wskazówki czy zalecenia: Model. Wprowadzasz go do fizycznej akcji, a on, przez jednakowe wymawianie sylab, nadaje auto ma ty cz nie głosowi brzmienie i modulacje właściwe swej prawdziwej naturze ${ }^{33}$. Model. Ograniczyć do minimum udział jego świadomości. Ujarzmić go tak, by mógł być tylko soba, by mógł robić tylko to, co przydatne ${ }^{34}$. Nie grajcie ani kogoś innego, ani siebie. Nie grajcie nikogo $o^{35}$. Żadnej psychologii (która odkrywa tylko to, co potrafi objaśnić) ${ }^{36}$. Jeśli modele-automaty (wszystko zważone, zmierzone, wyliczone co do minuty, powtórzone dziesięcio-, dwudziestokrotnie) wezma udziat w wydarzeniach przed kamera, wtedy ich zwiazki zosobami i przedmiotami będa trafne, bo nie przemyślane $e^{37}$. Każda z tych uwag znajduje praktyczne zastosowanie w późnych filmach Alana Clarke'a. Co więcej, Bresson, podkreślając potrzebę skrajnego behawioryzmu modeli, zaznacza ich relację i przełożenie na narrację, która (jak w Christine czy Słoniu) powinna być jak najbardziej „wypłaszczona”: Modele. Zdjęcia zmniejszaja ich trójwymiarowość, a zwiększaja ich szczerość i prawdziwość na ekranie. To najbardziej płaskie i bezbarwne partie filmu maja, ostatecznie, najwięcej życia ${ }^{38}$.

Pisząc natomiast o konstrukcji samej narracji, Bresson podkreśla wagę automatyzmu i radykalnej powściągliwości, stanowiących przecież zasadnicze cechy omawianych filmów: Dokładnie tyle, ile trzeba $a^{39}$; Usuń to wszystko, co rozprasza uwage ${ }^{40}$; Tworzy sie nie przez dodawanie, lecz ujmowanie. Rozwijanie watku jest czym innym ${ }^{41}$; Draż w miejscu. Nie zbaczaj. Chodzi o drugie, trzecie dno rzeczy ${ }^{42}$. Co ciekawe, nie tylko sama treść tych notatek, ale też ich zwięzłość językowa doskonale koresponduje ze stylem Clarke'a. Bresson ujął w nich nawet takie jakości, jak zmysłowy potencjał obrazów i zawartych w nich wzorów. Rozumiał, jak istotna jest „Widzialna mowa" ciał, przedmiotów, domów, ulic, drzew, pól ${ }^{43}$. Wiedział, czym jest Wszechpotęga rytmów. Trwałe tylko to, co ma rytm. Treść podporzadkować formie, a sens rytmowi ${ }^{44}$. Doświadczenie filmu powinno zaś pochodzić przede wszystkim od zmysłów i afektów: Zdjęcia. Polegać tylko na wrażeniach, na odczuciach. Bez interwencji rozumu, który jest im obcy ${ }^{45}$; Precz z mechanizmem intelektu lub mózgu. Po prostu sam mechanizm ${ }^{46}$. Najmocniejszą antycypacją stylu Clarke'a jest jednak myśl: Realność nie jest dramatyczna. Dramat rodzi się z pewnych działań elementów niedramatycznych ${ }^{47}$. Trudno o trafniejsze podsumowanie koncepcji narracyjnych Brytyjczyka.

\section{Ciało filmu i ciało widza}

Co wynika z zastosowania takiej strategii? Dlaczego i po co Clarke zdecydował się właśnie na taką, a nie inną formę? Być może odpowiedzi należy szukać w jego radykalizmie społecznym i politycznym. W żadnym ze wspomnianych filmów nie mówi się bezpośrednio o thatcheryzmie, a jednak każdy z nich jest gorzkim i jednoznacznym komentarzem do społecznych konsekwencji polityki 
rządu Margaret Thatcher. Made in Britain odnosi się do wytwarzania przez nowy system jednostek, które reprezentują narastające w tym czasie nastroje ultrakonserwatywne, ksenofobiczne i rasistowskie, przy jednoczesnym usuwaniu tych jednostek poza system jako patologicznych. Road pokazuje koszty społeczne deindustrializacji i gwałtownej prywatyzacji, a co za tym idzie - całkowity rozpad etosu proletariackiego i wspólnotowości. Christine oddaje nastrój skrajnej apatii przekładającej się na coraz poważniejsze problemy społeczne - nawet jeśli tym razem sceną jest nie osiedle robotnicze, ale schludna dzielnica niższej klasy średniej. Słoń stanowi próbę opisu i analizy konfliktu, którego zarówno geneza, jak i dynamika zależały bezpośrednio od posunięć rządu brytyjskiego (zaostrzony kurs wobec terroryzmu północnoirlandzkiego to jeden z filarów polityki Thatcher). Czy długie i monotonne ujęcia uporczywego marszu mogą wyrazić złożoność wszystkich tych problemów? Tak, jeśli przyjmiemy, że zrozumienie leży w procesie nie intelektualnym, ale zmysłowym. Zmysłowość zaś odnosi się do ciała zarówno filmu, jak i widza. Najkrócej rzecz ujmując, fizyczność i dynamika ciał na ekranie przenoszą się wprost na dyskomfort oglądającego.

Co z filmami Alana Clarke'a może zrobić widz? Jak wytłumaczyć tak wyraźnie cielesny efekt odbiorczy towarzyszący ich percypowaniu? Właściwy kontekst mogłyby zapewnić teorie afektywne. Stosunkowo rzadko jednak tematyzują one ciało samego filmu, a także te formy filmowe, które lokują się na antypodach tzw. gatunków cielesnych (jak horror czy film pornograficzny). A przecież praktycznie każdy film ma potencjał tego rodzaju oddziaływania, zwłaszcza taki, który na pierwszy plan wysuwa to, co Hill nazwał „wzorami kinetycznymi” - ciała, przestrzeni, kompozycji.

W przypadku kina Clarke'a mniejsze znaczenie ma to, co robią postacie na ekranie, niż to, jak właściwa im kinetyczność odbija się na ciele widza. Ich ruch nie odsyła więc do warstwy fabularnej, ale raczej formalnej, obrazowej. Reżyser wypycha figury postaci na powierzchnię, operując przede wszystkim rytmami, nie zdarzeniami. Byłaby to więc strategia ściśle somatograficzna, by posłużyć się terminologią wypracowaną przez Paulinę Kwiatkowską: Kamera zdejmuje płaskie wizerunki ciat, które komponowane w obrazie filmowym współistnieją z innymi elementami i na różne sposoby oddaja wrażenie głębi i trójwymiarowości. Jest to jednak zawsze głębia wtórnie wyinterpretowana, dana jest - przynajmniej z pozoru - wyłacznie powierzchnia i cielesny, mimiczny jedynie walor ekspresji aktorskiej, płaska czy raczej płaszczyznowa emocjonalność. (...) Funkcja ciała w obrazie filmowym nie jest bowiem tylko reprodukcja, czyli potwierdzanie realności czy materialności ciała, ale również kompozycja, która umożliwia konceptualizacje ciała - ujęcie go jako zarazem środka ekspresji i refleksji. Somatografia to pojęcie autorskie, które - by odwołać się do etymologii - ma skupiać się na sposobach zapisywania ciata w obrazie filmowym, w nawiazaniu do pojęcia kinematografii koncentrujacego się na zapisie ruch $u^{48}$. Ciało wpisane w kadr jest więc środkiem ekspresji i refleksji. Trzeba jednak przyjąć, że ekspresja ta w zetknięciu z widzem także musi mieć charakter cielesny. Przy tym nie chodzi tu o przyjemność, bo ruchome ciała ukazywane przez Clarke'a nie prezentują własnej zmysłowości w jej obiegowym (najczęściej erotyzowanym) ujęciu. Nie funkcjonują też same dla siebie - są jednym z elementów ciała filmu, motorem kinetyczności. Kinetyczność ta nie ogranicza się wyłącznie do płaszczyzny obrazu - wykracza poza niego, w stronę widza, obejmując go swoją dynamiką i energią. 
I tak dochodzimy do kwestii cielesnego odbioru filmu, doświadczania go na skórze, w mięśniach, w trzewiach. Właśnie taką triadę wyróżnia Jennifer M. Barker, opisując relację między ciałem na ekranie, ciałem widza a ciałem filmu. Barker widzi w tym ostatnim potencjał taktylności - film może jednocześnie być dotykany przez odbiorcę, jak i go dotykać. Taktylność ta nie jest po prostu cechą obrazu filmowego; badaczka odnosi to pojęcie do zasadniczej postawy ludzkiego ciała wobec kina, która oznacza otwarcie się jednego na drugie. Objawia się to na trzech poziomach: haptycznie, na czułej powierzchni ciała; kinestetycznie i mięśniowo - w muskułach, ścięgnach $i$ kościach, które sięgaja ku przestrzeni filmowej i poprzez nia; w trzewiach, nieprzeniknionych zakamarkach ciała, gdzie serce, płuca, pulsujace płyny, synapsy odbieraja, odpowiadaja na rytmy kina i je rekonstruuja ${ }^{49}$. Układ ten zostaje odzwierciedlony także w postawie nieludzkiego ciała filmu wobec świata (i widza). Haptyczność ujawniałaby się na powierzchni obrazu (...) w zadrapaniach, pyłkach i włóknach na taśmie; kinestetyka - w konturach przestrzeni ekranowej i pozaekranowej, w zarysach ciat, ludzkich i mechanicznych, które wypetniają bądź umykaja z tych przestrzeni; natomiast trzewia filmowe objawiają się w ruchu taśmy przez projektor i w "oddechu” soczewek ${ }^{50}$. Te dwie taktylności-dwóch autonomicznych, ale współoddziałujących ciał - cechuje wzajemność, nieustanny przepływ. Film działa na odbiorcę dlatego, że sam w sobie, jako byt cielesny, ma taką zdolność. Powierzchnia obrazu i wewnętrzne rytmy wywołują u nas gęsią skórkę, skurcz mięśni, przyspieszone (bądź spowolnione) bicie serca, a przede wszystkim - i to bezpośrednio dotyczy omawianych filmów Clarke'a - zgranie rytmu ciała widza z pulsem tego, co na ekranie.

Barker, idąc za Vivian Sobchack (a konkretnie za tezami z książki The Address of the $\left.E y e^{51}\right)$, a przez nią pośrednio za Maurice'em Merleau-Pontym i jego fenomenologią percepcji, uznaje, że istnienie filmu - tak jak ludzkie - jest ucieleśnione, a jako takie jest zdolne - jak ludzkie - zarówno do ekspresji, jak i do percepcji ${ }^{52}$. W doświadczeniu percepcja i ekspresja pozostaja w dynamicznej relacji odwracalności (ekspresja jest widocznym gestem percepcji), a więc żywe ciało zawsze jest w trakcie postrzegania ekspresji oraz wyrażania percepcji ${ }^{53}$. Jako żywe ciało film przedstawia nam własna percepcję (świata) i ekspresję (wobec świata) ${ }^{54}$ - w sposób jak najbardziej ucieleśniony.

Żywe ciało widza wchodzi z żywym ciałem filmu (innym, nie identycznym, ale obdarzonym podobnymi zdolnościami) w pole wzajemnego oddziaływania: skóra ze skóra, mięśnie z mięśniami, wnętrzności z wnętrznościami. Wszystkie te ciała - postaci, aktora, widza i filmu - to byty, których postawy i intencje sa wyrażane przez zachowania ucieleśnione ${ }^{55}$. Kontakt odbiorcy z filmem lokuje się w trudnej do jednoznacznego określenia przestrzeni pomiędzy tymi bytami. Ich granice są oczywiste, a jednak gdy wchodzą w relację, powierzchnie i kontury reagują ze sobą. Ogladając film, z pewnościa nie jesteśmy w nim, ale też nie jesteśmy całkowicie poza nim. Istniejemy, poruszamy sie i odczuwamy w przestrzeni kontaktu, gdzie nasze powierzchnie łącza się, a nasze miesśnie splataja ze soba. (...) Film i odbiorca sa intymnie spleceni, ale nie identyczni, pochwyceni w relacji intersubiektywności i wspólformowania. Nie stanowia przedmiotu i podmiotu usytuowanych po dwóch stronach ekranu ${ }^{56}$.

Ta wzajemność może tłumaczyć potencjalną reakcję widza na filmy Clarke’a. Koncepcje Barker (a więc także Sobchack i Merleau-Ponty'ego) wyjaśniałyby też siłę fizjologicznego oddziaływania tak odpsychologizowanych i zbehawioryzowanych obrazów. Tyle że skrajne przykłady Clarke'owskiego stylu - Christine i Słoń - nie oferują ostatecznie odczytania żadnych emocji zaszyfrowanych w za- 
chowaniach, ale nakazują widzowi zawierzenie własnemu ciału (reagującemu na ciało filmu w przestrzeni kontaktu), odczuciom na skórze, w mięśniach i wnętrznościach. Uzgodnienie cielesnych rytmów widza i filmu nie ma charakteru mimetycznego, ale samo w sobie stanowi rozumienie tego, co mówi film. Treścią tego, co możemy zrozumieć z dzieł Clarke’a, jest inercja, która wyraża się w niepohamowanym, kompulsywnym, nieukierunkowanym ruchu, w cykliczności, skrajnym behawioryzmie, blokadzie identyfikacji z postacią przy jednoczesnej niemożności ucieczki od niej. W niekończącym się, uporczywym marszu zawiera się ogromna, choć trwoniona energia - energia, która wypływa z inercji.

\section{Epilog}

W 2003 r. Gus Van Sant zrealizował, jak wspomniałam, film będący swoistym powtórzeniem Słonia Alana Clarke’a, choć zapewne niewiele osób wiedziało (biorąc pod uwagę dość wąski odbiór twórczości Brytyjczyka) o tej bezpośredniej inspiracji. Dzieło Van Santa także tematyzowało przemoc; reżyser odniósł się w nim do prawdziwych wydarzeń z kwietnia 1999 r., tzw. masakry w Columbine High School, kiedy dwóch nastolatków zastrzeliło dwanaścioro innych uczniów i jednego nauczyciela, raniąc przy tym kilkadziesiąt osób. Van Sant, zgodnie ze swoimi poszukiwaniami twórczymi, odszedł od klasycznej linearnej narracji, nie próbował też rozpoznać czy tłumaczyć motywacji zabójców. Jego Słoń jest daleki od dokumentalizmu. Dzień masakry przedstawił natomiast w kilku narracjach, prowadzonych niejako z perspektywy różnych bohaterów - świadków, ofiar i zabójców. Ogląd jednego wydarzenia rozbił na poszczególne trajektorie narracyjne, przecinające się wzajemnie i uzupełniające. Jednak każda z tych ścieżek czy też nitek także odchodzi od klasycznego sposobu opowiadania. Van Sant powtarza strategię Słonia Clarke'owskiego: rezygnując z montażu, decyduje się na długie ujęcia postaci wędrujących szkolnymi korytarzami, najczęściej sytuując kamerę za ich plecami. Znów więc mamy do czynienia z hipnotyczna, afabularną płynnością i transowością miarowych kroków. Jest też repetycyjność, czy może zapętlenie, bo te same sytuacje powracają w „relac-

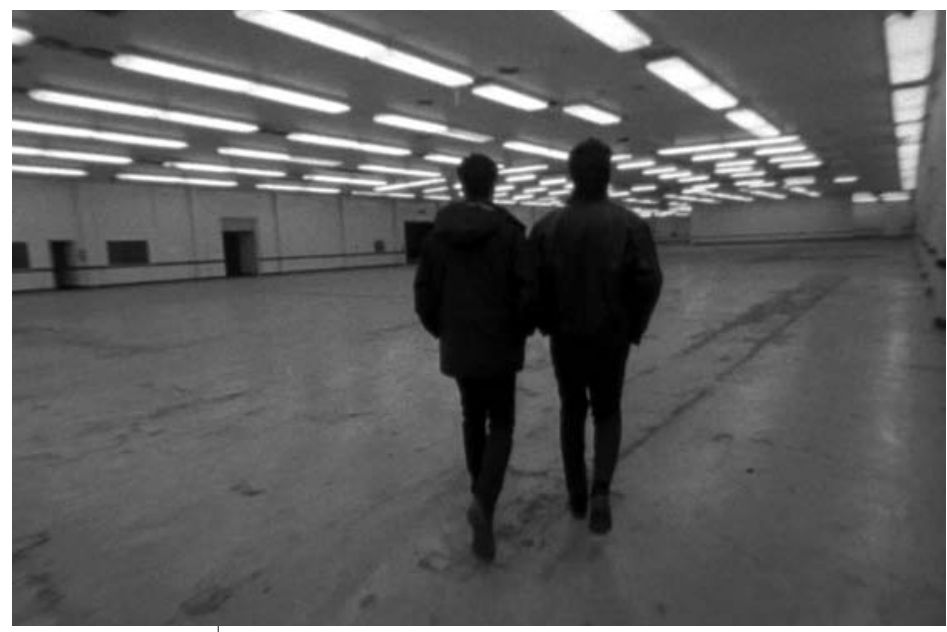

Słoń, rè̇. Alan Clarke (1989) 

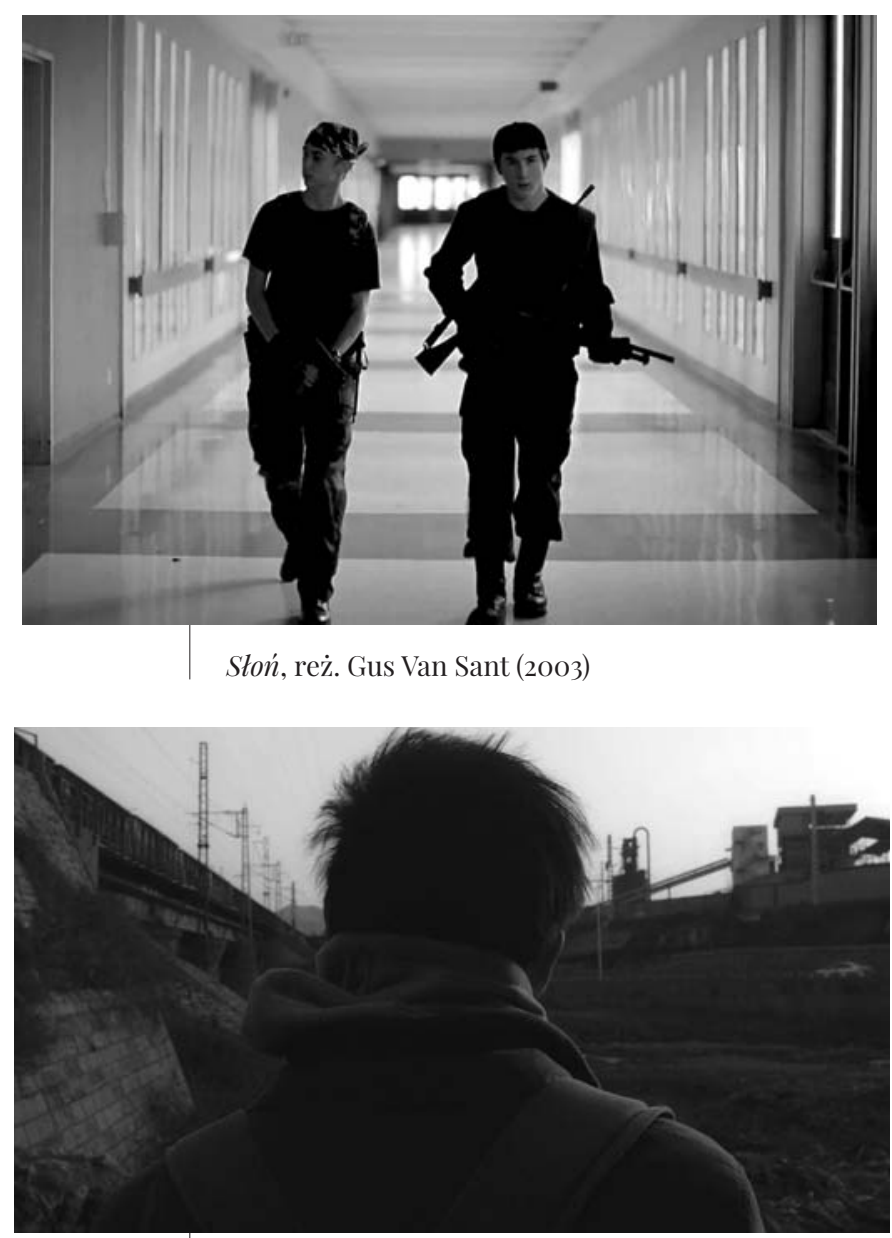

Siedzacy słoń, reż. Hu Bo (2018)

jach" z różnych perspektyw. Tyle że monotonny, kołyszący rytm prowadzi nas do jednego tylko wstrząsu, jakim jest strzelanina. Natomiast efekt obcości i przymusu świadkowania, a ostatecznie skrajnego dyskomfortu jest tu dokładnie ten sam.

Jakiego rodzaju ćwiczenie - na narracji i na samych widzach - chciał przeprowadzić Gus Van Sant, tak skrupulatnie powtarzając strategię Clarke'a i niejako sklejając swój film z pierwowzorem (jeśli można tak nazwać Stonia z 1989 r.) przez nadanie mu takiego samego tytułu? I czy jego gest można nazwać cytatem? Wydaje się, że Amerykanin nie cytuje w sensie dosłownym, ale wykorzystuje ten sam chwyt, nadając swojemu dziełu metaramę, jakby mówił: „Patrzcie, cytuję” albo "Patrzcie, znów to samo". Stoń Van Santa dialoguje nie tylko z widzem, ale i ze Stoniem Clarke'a. Film z 2003 r. nie sprawia wrażenia powtórzenia; to dzieło w pełni autorskie, doskonale wpisujące się w poetykę właściwą całej twórczości Van Santa. Być może więc chodzi tu o pokrewieństwo, o dialog właśnie, o zbadanie, czy sprawdza się wzajemne oddziaływanie tych dwóch filmowych ciał, tak podobnych. Co więcej, Van Sant wyraźnie określa odrębność własnej pozycji oraz intencji, inaczej też tłumaczy figurę tytułowego słonia, ściśle splatając tę eksplikację 
ze strukturą filmu; przywołuje chińskie przysłowie: Jeśli weźmiemy pięciu ślepych ludzi, dla każdego z nich słoń będzie czym innym: dla jednego będzie ściana, dla innego lina, dla kolejnego drzewem, a dla jeszcze kolejnego wężem... To kwestia, na która nie ma odpowiedzi ${ }^{57}$. Rozbicie narracji na kilka subnarracji (opowiadających w zasadzie o tym samym) stanowi przełożenie tak postawionego problemu. Van Sant nie polega na Clarke'u; opowiadając o masakrze w Columbine, mówi własnym głosem - a jednocześnie w bezpośrednim geście wskazuje antycypację w postaci Słonia północnoirlandzkiego. Dialogu obu tych filmów nie da się zignorować. Być może zasadniczym elementem tej rozmowy jest właśnie dyskomfort wynikający z obcości: Tym, co rzeczywiście ogladacie przez cały czas, jest przemieszczenie i oderwanie mówi Van Sant ${ }^{58}$. I choć dalej łączy ten stan zakłócenia i rozbicia z relacjami uczniów i nauczycielami jako figurami władzy, uważny widz dokładnie wyczuje, że chodzi o sprawy bardziej uniwersalne. Wszystko to jest skrzywione, wyczerpane. Myśle, że nasze życie właśnie tak wyglada ${ }^{59}$.

Piętnaście lat po realizacji Słonia Gusa Van Santa na licznych festiwalach głośnym echem odbiły się projekcje Siedzącego słonia (Elephant Sitting Still / Da xiang xi di er zuo, 2018) - debiutu chińskiego reżysera Hu Bo. Sam twórca nie doczekał premiery - w październiku 2017 r. popełnił samobójstwo. Monumentalne, niemal czterogodzinne dzieło okazało się ważnym wydarzeniem filmowym, a przedwczesna śmierć 29-letniego reżysera nadała filmowi ton tragiczny. Środowisko filmowe, które doskonale przyjęło Siedzącego słonia, także było wstrząśnięte. W emocjonalnym liście do publiczności Béla Tarr, mentor Hu Bo, pisał, jak wielką osobowość straciło kino ${ }^{60}$. Sam film przedstawia ponury obraz współczesnych Chin, niemożność wyrwania się z kręgu desperacji, nędzy i apatii. Wiele wątków tej opowieści łączy figura młodego chłopaka, Wei Bu - wiecznie w ruchu, w drodze, która trwa i której punkt dojścia nieustannie się odsuwa. Nadzwyczaj często wędrujący od celu do celu bohater jest filmowany zza pleców, w długich scenach uporczywego marszu. Hu Bo nie pozostawił wyjaśnień pozwalających złączyć go z Alanem Clarkiem i Gusem Van Santem. Jednakże tytułowa metafora słonia, odsyłająca do figury zwierzęcia cyrkowego, które niewzruszenie siedzi i trwa, nieczułe na ciosy zadawane mu przez świat, mówi bardzo wiele.

${ }^{1}$ Fraza ta została zapożyczona od irlandzkiego pisarza Bernarda MacLaverty'ego, który w ten sposób chciał opisać mechanizm wyparcia dotyczący sytuacji konfliktu w Irlandii Północnej (Alan Clarke, red. R. Kelly, Faber and Faber, London 1998, s. 193-194).

${ }^{2}$ W źródłach są podawane rozmaite daty produkcji wskazanych tytułów, ja jednak trzymam się datowania podanego w książce Dave'a Rolinsona (D. Rolinson, Alan Clarke, Manchester University Press, Manchester New York 2011).

${ }^{3}$ Alan Clarke, dz. cyt., s. XIV.

${ }^{4}$ Zob. https://www.theguardian.com/film/2002/feb/01/artsfeatures1 (dostęp: 16.03.2021).

${ }^{5}$ W 1979 r. Clarke zrealizował kinową wersję telewizyjnego oryginału z 1977 r.
${ }^{6}$ Almost Holy: Harmony Korine Talks to Geoffrey Macnab, "Sight and Sound” 1998, nr 4, s. 26.

${ }^{7}$ Pomijam w tym zestawieniu jeden $\mathrm{z}$ najbardziej znanych filmów Clarke'a - Rita, Sue i Bob (Rita, Sue and Bob Too, 1987), adaptację dramatu Andrei Dunbar. Ta prowokacyjna komedia, rozgrywająca się $\mathrm{w}$ robotniczej dzielnicy Bradford, ma zaskakująco konwencjonalną strukturę i jako taka odbiega od pozostałych omawianych tu filmów.

${ }^{8}$ Alan Clarke, dz. cyt., s. 147.

${ }^{9}$ D. Rolinson, dz. cyt., s. 115.

${ }^{10} \mathrm{~J}$. Hill, From the New Wave to "Brit Grit": Continuity and Difference in Working-class Realism, w: British Cinema, Past and Present, red. J. Ashby, A. Higson, Routledge, London - New York 2006, s. 258. 
11 Tamże.

${ }^{12}$ Alan Clarke, dz. cyt., s. 166.

${ }^{13}$ Także dlatego, że - jak słusznie obawiał się Ellis - BBC nigdy nie zdecydowałaby się pokazać dosłownych obrazów wstrzykiwania przez narkomanów heroiny w jedyne miejsca na ciele, które jeszcze przyjęłyby narkotyk (np. oko czy członka).

${ }^{14} \mathrm{~W}$ filmie $\mathrm{z}$ pewnością jest kilka lat starsza.

${ }^{15}$ Alan Clarke, dz. cyt., s. 166.

16 Tamże, s. 170

${ }^{17}$ M. Walsh, Thinking the Unthinkable: Coming to Terms with Northern Ireland in the $1980 \mathrm{~s}$ and 1990s, w: British Cinema... dz. cyt., s. 296.

18 Tamże.

${ }^{19}$ Zob. D. Rolinson, dz. cyt., s. 129.

${ }^{20}$ Alan Clarke, dz. cyt., s. 198.

${ }^{21}$ Zob. D. Rolinson, dz. cyt., s. 107.

22 Tamże.

${ }^{23}$ Tamże.

${ }^{24}$ H. Schuman, Alan Clarke: In It for Life, „,Sight and Sound" 1998, nr 9, s. 20.

${ }^{25}$ D. Rolinson, dz. cyt., s. 107.

26 Tamże, s. 103.

27 A. Clifford, The "Scum" Manifesto, "The Guardian", 16.07.1991, s. 30.

${ }^{28}$ R. Kelly, dz. cyt., s. 74.

${ }^{29}$ Brecht był bliski także Clarke' owi - na podstawie jego tekstu reżyser zrealizował film Baal (1982), w którym główną rolę zagrał David Bowie.

${ }^{30}$ S. Sontag, Duchowy styl filmów Roberta Bressona, tłum. D. Żukowski, w: tejże, Przeciw interpretacji $i$ inne eseje (tłum. M. Pasicka, A. Skucińska, D. Żukowski), Karakter, Kraków 2012, s. 242.

${ }^{31}$ R. Bresson, Notatki o kinematografie, tłum. A. Ledóchowski, „Film na Świecie” 1983, nr 300, s. 15.

32 Tamże, s. 25.

33 Tamże.
34 Tamże, s. 32.

35 Tamże, s. 36.

36 Tamże, s. 42.

37 Tamże. s. 22.

38 Tamże, s. 39.

39 Tamże, s. 28.

40 Tamże, s. 45.

41 Tamże, s. 47.

42 Tamże, s. 21.

43 Tamże, s. 19.

44 Tamże, s. 36.

45 Tamże, s. 26.

${ }^{46}$ Tamże.

47 Tamże, s. 47.

${ }^{48}$ P. Kwiatkowska, Somatografia. Ciało w obrazie filmowym, Korporacja Ha!art, Kraków 2011, s. 34.

${ }^{49}$ J. M. Barker, The Tactile Eye: Touch and the Cinematic Experience, University of California Press, Berkeley - Los Angeles - London 2009, s. 3.

${ }^{50}$ Tamże.

${ }^{51}$ Zob. V. Sobchack, The Address of the Eye: A Phenomenology of Film Experience, Princeton University Press, Princeton 1992.

${ }^{52}$ J. M. Barker, dz. cyt., s. 8.

${ }^{53}$ Tamże, s. 8. Zob. V. Sobchack, dz. cyt., s. 123-143 .

${ }^{54}$ J. M. Barker, dz. cyt., s. 9.

55 Tamże, s. 10.

56 Tamże, s. 12-13.

${ }^{57}$ Cyt. za: A. Taubin, K. Jones, Part of the Problem, „Film Comment" 2003, wrzesień-październik, s. 26-27.

58 Tamże, s. 33.

59 Tamże.

60 Treść tego listu można przeczytać tutaj: https://www.nowehoryzonty.pl/akt.do?lang =en\&id=5388 (dostęp: 20.03.2021).

\section{Karolina Kosińska}

Doktor filmoznawstwa, adiunkt w Zakładzie Antropologii Kultury, Filmu i Sztuki Audiowizualnej w Instytucie Sztuki Polskiej Akademii Nauk. Redaktorka naczelna „Kwartalnika Filmowego". Autorka książki Androgyn. Tożsamość, tęsknota, pragnienie (2015), uhonorowanej Nagrodą im. Bolesława Michałka za najlepszą książkę filmoznawczą roku. Zainteresowania naukowe: brytyjskie kino społeczne i formy filmowego realizmu społecznego. 


\section{Bibliografia}

Barker, J. M. (2009). The Tactile Eye: Touch and the Cinematic Experience. Berkeley - Los Angeles - London: University of California Press.

Bresson, R. (1983). Notatki o kinematografie (thum. A. Ledóchowski). Film na Śriecie, (300), Ss. 15-47.

Clifford, A. (1991, 16 lipca). The „Scum” Manifesto. The Guardian, s. 30.

Hill, J. (2006). From the New Wave to „Brit Grit”: Continuity and Difference in Working-class Realism. W: J. Ashby, A. Higson (red.), British Cinema, Past and Present (ss. 249-260). London - New York: Routledge.

Kelly, R. (red.) (1998). Alan Clarke. London: Faber and Faber.

Kwiatkowska, P. (2011). Somatografia. Ciało w obrazie filmowym. Kraków: Korporacja Ha!art.

Rolinson, D. (2011). Alan Clarke. Manchester - New York: Manchester University Press.

Schuman, H. (1998). Alan Clarke: In It for Life. Sight and Sound, (9), ss. 19-20.

Sontag, S. (2012). Duchowy styl filmów Roberta Bressona (tłum. D. Żukowski, publikacja oryginału: 1964). W: S. Sontag. Przeciw interpretacji i inne eseje (thum. M. Pasicka, A. Skucińska, D. Żukowski, ss. 237-261). Kraków: Karakter.

Taubin, A., Jones, K. (2003). Part of the Problem. Film Comment, (5), ss. 26-33.

Walsh, M. (2006). Thinking the Unthinkable: Coming to Terms with Northern Ireland in the 1980 os and 1990s. W: J. Ashby, A. Higson (red.), British Cinema, Past and Present (ss. 288-298). London - New York: Routledge.

\author{
Keywords: \\ Alan Clarke; \\ Robert Bresson; \\ identification; \\ behaviourism \\ in cinema; \\ bodily perception \\ of cinema; \\ British cinema
}

\section{Abstract \\ Karolina Kosińska}

This Is Your Man - Go with Him: About the Disrupted Identification in the Films of Alan Clarke

Alan Clarke's later films - like Made in Britain (1983), Christine (1987), Elephant (1989) - reveal a fully crystalized, mature creative strategy of the director. This strategy is defined by extreme reduction and repetitiveness of the narrative, emphasis on the compulsiveness of the characters' actions, concentration on behavioural aspects combined with a radical rejection of psychology. It is realized primarily through long "walking" shots, and it results in a corporeal, translike experience of the film, in a specific relationship of the viewer with the characters and also, consequently, with the body of the film itself. Clarke forces on the viewer the constant contact with the human figure on the screen, while methodically depriving him or her of the possibility of identification. The author problematizes this disturbed identification by analyzing Alan Clarke's films and by situating them in the context of Robert Bresson's Notes on Cinematography, which in a way anticipate Clarke's style, and also in relation to the theoretical concepts of bodily perception of the cinema developed by Jennifer M. Barker. 